\author{
Małgorzata Marcinkowska-Malara \\ Uniwersytet Śląski w Katowicach \\ gosia1134@wp.pl
}

\title{
Modlitwa o zachowanie czystości z drugiej połowy XVIII wieku
}

\section{Abstract \\ Modlitwa o zachowanie czystości, from the second half of the $18^{\text {th }}$ century}

The paper, preceded by a brief introduction, contains an edition of an anonymous print entitled Modlitwa o zachowanie czystości (A prayer for the preservation of purity). It was conventionally dated to the second half of the $18^{\text {th }}$ century. The introduction depicts the socio-moral and religious context of the prayer and argues that the genesis of the text is strongly connected with the described circumstances. The author of the text also paid attention to the genre pattern of the prayer and compared it with similar writings occurring in contemporary prayer books.

The volume includes: the text of the title prayer, enumerated admonitions regarding benefits of chastity and the ways of its preservation, as well as dangers that a virtuous lady should avoid. Introductory remarks, explanations and comments, which were added to the texts of an unknown author, helped to fully understand the old print. They also describe the structure and purpose of the collection, and discuss its elements, which are characteristic of catechism, parenesis, and the examination of conscience.

The Prayer for the preservation of purity occupies a significant place among enlightenment prayer prints. In fact, it is quite an extensive collection of persuasive texts entirely dedicated to one particular virtue. Its form, corresponding to the prayer genre, was designed to strengthen the importance of the textual message included in this print and to give the texts catechetical and educational meaning. The collection was not published in self-editing form, nor was it added to any prayer 
book at that time. It may be assumed that chastity, as a virtue, was not so important and not promoted, for example, in young aristocratic and noblewoman's education.

Key words: Enlightenment, prayer, purity, moralisation, parenesis

W Polsce w drugiej połowie XVIII wieku kobiety ze środowisk magnackich i z kręgów zamożnej szlachty uzyskały w życiu towarzyskim dużo większą swobodę niż w wiekach poprzednich. Wielokrotnie pisano już o ich rosnących aspiracjach i aktywności, o zamiłowaniu do różnorodnych rozrywek, między innymi teatru, muzyki, podróży, mody ${ }^{1}$. Przedstawicielki magnackich rodów sporo czytały, nierzadko same sięgały po pióro, a przy tym niejednokrotnie inspirująco oddziaływały na literatów oraz artystów². Wyraźna zmiana w sferze obyczajowej i społecznej, wiążąca się z rosnącą niezależnością kobiet, bywała przedmiotem krytycznych uwag i opinii, między innymi w anonimowych drukach, w sposób parodystyczny ujmujących wizerunki pań różnego wieku i stanu. Warto wspomnieć choćby o interesujących ze względu na walory ludyczne modlitwach dla panien i mężatek. W tekstach tych akcentowane są obiegowe wady płci nie-

1 Zob. K. Stasiewicz, Kobiece przyjemności w XVIII wieku, w: Przyjemność w kulturze epoki rozumu, red. T. Kostkiewiczowa, Warszawa 2011, s. 125-146.

2 Zob. m.in. J. Skowronek, Debiuty polityczne kobiet w epoce rozbiorowej i początkach epoki porozbiorowej 1772-1831, w: Pamiętnik XV Powszechnego Zjazdu Historyków Polskich, t. 2: Przemiany społeczne a model rodziny, red. A. Żarnowska, Gdańsk 1995, s. 29-41; A. Aleksandrowicz, Izabela Czartoryska. Polskość i europejskość, Lublin 1998; J. Sawicka-Jurek, „Pod wdzięcznym onej rozkazem” - o kulturotwórczej roli dworu Aleksandry Ogińskiej w Siedlcach, w: Dwory magnackie $w$ XVIII wieku. Rola i znaczenie kulturowe, red. T. Kostkiewiczowa, A. Roćko, Warszawa 2005, s. 263-273; R. Ryba, „Jej portret” - postaci kobiet $w$ osiemnastowiecznych listach dedykacyjnych, w: Dedykacje $w$ ksiażce dawnej $i$ współczesnej, red. R. Ocieczek, A. Sitkowa, Katowice 2006, s. 113-125; A. Jakuboszczak, Sarmacka dama. Barbara Sanguszkowa (1718-1791) i jej salon towarzyski, Poznań 2008. 
wieściej, takie jak plotkarstwo, ciekawska natura, próżność, a ponadto nieporadność życiowa kobiet oraz konieczność zachowania ich całkowitej zależności od mężczyzn ${ }^{3}$.

Negatywne zjawiska krytycznie oceniane przez pisarzy tego czasu wiązały się przede wszystkim z bardzo silnym, znacznie szerzej zakrojonym niż w XVII wieku oddziaływaniem kultury francuskiej, a zwłaszcza ze znacznie wzmożonym w stosunku do minionego okresu przenikaniem do kraju nieskromnej (jak na polskie realia obyczajowe) damskiej mody ${ }^{4}$ oraz tendencji hedonistycznych i libertyńskich ${ }^{5}$.

3 Zob. m.in. następujące edycje: Modlitwa pożyteczna i wielce potrzebna młodej panience, która żąda być opatrzoną, jak się należy świętym sakramentem małżeństwa, w: Katechizm amanta, Jasna Góra 1760, s. 14-15; wydane w drugiej połowie XVIII wieku: Modlitwy panien żądających męża, [b.m.r.] - przypomniane we wspó1czesnym wydaniu: Modlitwy kobiet „przyjaciela gwałtem potrzebujacych”, czyli o zapomnianej parodii pobożności niewiast z przełomu XVIII i XIX w., oprac. M. Lenart, Opole 2015 - oraz Pieśń lamentującej kobiety bez gorzałki, [b.m.r.]; ponadto: Wieczory zabawne, czyli rozrywka dla dam i kawalerów $w$ rozmaitych ciekawych $i$ dowcipnych wierszach $i$ anegdotach $z$ przyłaczeniem sto i oko zagadek, Warszawa 1805; a także wydane w Krakowie około roku 1830 Mieszaniny, czyli zbiór wierszów luźnych wydanych od roku 1820 do roku 1825.

4 Kobieca moda czerpiąca wówczas wzory z Francji zalecała suknie przezroczyste, z głębokim dekoltem, odsłaniające kobiece ciało, a zatem sprzyjające sztuce uwodzenia. Popularne były także atłasy, koronki i kornety, które „karmiły” próżność ówczesnych dam. Zob. J. Kitowicz, Opis obyczajów za panowania Augusta III, wstęp M. Dernałowicz, red., komentarz i wybór ilustracji Z. Goliński, oprac. tekstu, indeksy zestawiła A. Skarżyńska, Warszawa 1985, s. 261-267. O zróżnicowanych reakcjach ówczesnych literatów na strojenie się kobiet w takie suknie piszą Joanna Mazur i Kamila Rogowicz, Literaci XVIII wieku o kobiecych piersiach i dekoltach, w: Wiek XVIII (nie tylko) w szkole. Literatura - historia kultura - sztuka, red. B. Mazurkowa, z udziałem M. Marcinkowskiej, Katowice 2013, s. 135-145.

5 Wielokrotnie już podkreślano, że w drugiej połowie XVIII wieku szerzyły się postawy hedonistyczne i epikurejskie. Popularność zyskały również idee libertyńskie, skupione na poszukiwaniu wolności, niezależności i rozkoszy cielesnej. Zob. E. Aleksandrowska, Problem zdrady na podstawie „Satyr i pamfletów na Polki balujace $w$ czasach tragicznych dla ojczyzny” (1774-1832), w: „Bo insza jest rzecz zdradzić, insza dać się złudzić". Problem zdrady w Polsce przełomu XVIII i XIX w., 
W oświeceniu na niespotykaną wcześniej skalę szerzył się nierząd, na co niemały wpływ mieli pochodzący z wyższych sfer klienci domów publicznych ${ }^{6}$. Mimo ustanowionej formalnie na soborze trydenckim szczególnej rangi dziewictwa ${ }^{7}$, w omawianym okresie nieliczne wzmianki o cnocie czystości i zachęty do jej zachowania zamieszczano (co zrozumiałe) w tekstach dedykowanych głównie osobom zakonnym oraz przedstawicielom duchowieństwa ${ }^{8}$. Nawet $\mathrm{w}$ ówczesnych modlitewnikach rzadko podejmowano zagadnienia

red. A. Grześkowiak-Krwawicz, Warszawa 1995, s. 115-131; K. Stasiewicz, Kobiece przyjemności w XVIII wieku, w: Przyjemność w kulturze epoki rozumu, red. T. Kostkiewiczowa, Warszawa 2011, s. 125-146; M. Dębowski, Zabawy przyjemne i pożyteczne $w$ oświeconej alkowie, w: Przyjemność w kulturze epoki rozumu..., s. 111-124; J. Snopek, Objawienie i Oświecenie: $z$ dziejów libertynizmu w Polsce, Wrocław 1986; idem, Libertynizm, w: Słownik literatury polskiego oświecenia, red. T. Kostkiewiczowa, wyd. 2 poszerzone i poprawione, Wrocław 1991, s. 269-274.

6 O społecznych uwarunkowaniach oraz obyczajowych i zdrowotnych konsekwencjach drastycznego wzrostu prostytucji w Polsce w drugiej połowie XVIII wieku pisze Magdalena Ślusarska, Przyjemności „wszeteczne”, czyli o prostytucji w Warszawie stanisławowskiej, w: Przyjemność w kulturze epoki rozumu..., s. 147179. Zob. także A. Krosny, Z ulicy na salony. Awans społeczny w świecie prostytucji w wieku XVIII, w: Wiek XVIII (nie tylko) w szkole..., s. 123-133.

7 Uprzywilejowanie dziewictwa uzyskało oficjalne potwierdzenie na soborze trydenckim w kanonie X dekretu o sakramencie małżeństwa, który został ogłoszony 11 listopada 1563 roku: „Si quis dixerit, statum conjugalem anteponendum esse statui virginitatis vel cælibatus, et non esse melius ac beatius manere in virginitate aut cælibatu, quam jungi matrimonio: anathema sit” („Jeśli ktoś rzekłby, że stan małżeński należy wyżej cenić niż stan dziewictwa lub celibatu i że zachowywanie stanu dziewictwa lub celibatu nie jest lepsze i szczęśliwsze niż zawieranie małżeństwa - niech będzie przeklęty!” - tłum. Marek Job). Łaciński i angielski zapis tego dekretu zob. na stronie: http://www.ccel.org/ccel/schaff/creeds2.v.i.i.xi.html [dostęp: 13.07. 2016].

8 Zob. m.in. S.W. Michałowski, Przestrogi i uwagi nad obowiązkami każdego stanu, pobudzające chrześcijan do zadosyć czynienia powołaniu ich. Dzieło pożyteczne wszystkim, którzy żyć pragna duchem prawdziwej i gruntownej pobożności, wyd. najprzód w francuskim języku, z francuskiego na włoski, a teraz z włoskiego na polski język przetłumaczone przez jednego zakonnika Scholarum Piarum, książka pierwsza, Warszawa 1768; F. Salezy, Przestroga dla spowiedników, sposób odprawowania pobożnie mszy świętej, przygotowanie się do komunii świętej przez 
z tym związane, a krótka Modlitwa o czystość trafiła zaledwie do kilku wydań z XVIII stulecia ${ }^{9}$. Stąd zainteresowanie wzbudza druk zatytułowany Modlitwa o zachowanie czystości ${ }^{10}$. Anonimowa edycja jest tym cenniejsza, że według informacji zawartych w Centralnym Katalogu Starych Druków Biblioteki Narodowej w Warszawie zachował się tylko jeden jej egzemplarz, obecnie należący do zbiorów Biblioteki Uniwersytetu Warszawskiego. W druku liczącym dwadzieścia cztery strony można wyodrębnić trzy wyraziste części. Pierwsza zawiera tytułowy tekst; druga obejmuje ujęte w sposób tradycyjny, według nauki Kościoła, Biblii, kazań, religijnych i moralizatorskich traktatów, przestrogi, na które składają się trzy rozdziały skomponowane w formie punktów: „Pożytki cnoty czystości”; „Niebezpieczeństwa, których się cnotliwa panienka osobliwie strzec ma” oraz „Śrzodki do zachowania panieńskiej czystości”; w ostatniej części znajdują się modlitwy skierowane do Maryi, Jezusa i świętych ${ }^{11}$.

Publikacja rozpoczynająca się od tytułowego tekstu skłania czytelnika do określonego sposobu odbioru - postawy wynikającej z wiary w słuszność zawartych w tekście pouczeń i przestróg. Ów tekst tylko pozornie wpisuje się jednak w schemat wskazanego ga-

uwagi zbawienne, akty różne strzeliste, modlitwy i zabawy pobożne, $\mathrm{z}$ francuskiego na polskie przetłumaczone, Kraków 1793.

9 Zob. m.in. tekst Modlitwy o czystość w edycjach: Dama pokutująca przez codzienne nabożeństwa $z$ Bogiem i Matka Boską, jako też źświętymi patronami i patronkami swoimi nieustanie rozmawiajaca wszystkim prawdziwie pokutujacym do naśladowania podana, Sandomierz 1740, s. 668; Oficium abo Godziny błogostawionej Panny Maryi, z rozkazania Piusa Piatego papieża wydane, niedawno reformowane, a teraz nowo poprawione, $z$ oficium za dusze zmarte, $z$ inszymi różnymi modlitwami obojej płci służacymi przydane, Lublin 1754, s. 603.

10 Modlitwa o zachowanie czystości, [b.m.r.]. Zob. K. Estreicher, Bibliografia polska, cz. 3, t. 11 (22), Kraków 1908, s. 483.

11 Warto zwrócić uwagę na porównanie omawianego druku z przestrogami o zachowaniu czystości Jakuba Kulczyckiego (1796); zob. M. Marcinkowska, Anonymous 18th Century Publication Dedicated to the Virtue of Purity, „Religious and Sacred Poetry" 4 (2014), s. 73-84. 
tunku ${ }^{12}$. Wprawdzie zawiera ramę tekstową (ze składnikiem inicjalnym - tytułem oraz finalną aklamacją Amen), inwokację do adresata ze sfery sacrum („Wszechmogący a nieograniczony Boże!”) oraz liczne prośby modlącego się podmiotu („spraw to”, „broń”, „zachowaj”), lecz cel aktu komunikacji wpisanego w ten przekaz daleki jest od tego, który charakteryzuje modlitwę. Omawiany druk został prawdopodobnie napisany z myślą o młodych, szlachetnie urodzonych, posażnych pannach. Świadczy o tym przywołanie w tekście realiów znamiennych dla kobiet $\mathrm{z}$ tego właśnie kręgu społecznego (kosztowne stroje, komplementy w towarzystwie). Nieznany autor posłużył się uświęconym przez tradycję schematem gatunkowym o biblijnej proweniencji, aby przypomnieć o randze czystości, skłonić niezamężne kobiety do jej zachowania, a także przekazać im określone przez katechizm i naukę Kościoła poglądy na temat pielęgnowania bądź skutków utraty owej cnoty. Warto zwrócić uwagę na konkretne zalecenia oraz liczne pytania retoryczne, ujęte w formie pierwszej osoby liczby pojedynczej i wskutek tego zbliżone konstrukcyjnie do rachunku sumienia. Sformułowania te skłaniały modlące się panny do refleksji nad własnym postępowaniem, a także do świadomego podejmowania decyzji w sprawach, które w ostatecznym rozrachunku przesądzą o zbawieniu bądź potępieniu na wieczność.

W drugiej części tego druku autor nakazuje pannie dystans w kontaktach z mężczyznami prawiącymi komplementy. Stosuje perswazje opartą na dychotomicznym wartościowaniu korzyści i szkód, jakie przynosi pielęgnowanie bądź odrzucenie charakteryzowanej i zalecanej cnoty. Kolejno najpierw wskazuje konkretny skutek nieczystości, a następnie przeciwny do tego efekt życia w czystości. Najważniejszym celem tak skonstruowanej wypowiedzi moralizatorskiej jest pouczenie błądzących oraz skłonienie ich do zmiany postępowania. Funkcja tego zabiegu zasadza się na pozornej jedynie

12 Zob. M. Wojtak, Modlitwa ustalona - podstawowe wyznaczniki gatunku, w: W zwierciadle języka i kultury, red. J. Adamowski, S. Niebrzegowska, Lublin 1999, s. 129-137. 
możliwości wyboru, ponieważ jednoznacznie wskazane i waloryzowane są zalecane wartości, postawy oraz zachowania. W sposób oczywisty chwilowe przyjemności doczesne nie mogą konkurować z obietnicą szczęścia wiecznego. Najmniejszej wątpliwości nie budzi decyzja, która dotyczy wyboru między życiem a śmiercią, między błogosławieństwem a przekleństwem.

Ostatnią, trzecią część druku, której nie obejmuje opracowana edycja, tworzą następujące teksty modlitewne: Koronka do Najświętszej Maryi Panny Niepokalanego Poczęcia, Ofiarowanie samej siebie Najświętszej Maryi Pannie, Krótka modlitewka do Najświętszej Maryi Panny Niepokalanego Poczęcia, Modlitwa do św. Józefa, Modlitwa do św. Jana Ewangelisty i Stanisława Kostki, Prośba do Pana Jezusa oraz Modlitwa druga. Do Matki Boga kierowane są prośby o wstawiennictwo, a także pełne ufności akty zawierzenia życia, woli i rozsądku, natomiast pozostali święci upraszani są o chronienie modlących się panien przed niebezpieczeństwami świata, nieczystości i pożądliwości. Zamykające zbiorek modlitwy do Jezusa mają charakter pasyjny - według nieznanego autora wspomnienie Chrystusowych ran, cierpień i śmierci krzyżowej powinno być dla wierzących pocieszeniem i pokrzepieniem w trudnych sytuacjach i przeciwnościach życiowych.

Modlitwa o zachowanie czystości to różnorodny, ale spójny tematycznie zbiór, który w zamierzeniu autora miał pełnić funkcję nie tylko modlitewnika, ale także parenezy, rachunku sumienia, a nawet katechizmu. Warto podkreślić, że stanowi on ewenement pośród oświeceniowych druków modlitewnych. Jest to prawdopodobnie jedyne ówcześnie tak obszerne dzieło o charakterze perswazyjnym, które zostało poświęcone konkretnej cnocie.

Fakt, iż w charakteryzowanej edycji zawarte są liczne aluzje bądź bezpośrednie odwołania do negatywnych zjawisk obyczajowych, które nasiliły się w dobie stanisławowskiej, skłania do przypuszczeń, że dzieło to mogło powstać właśnie w drugiej połowie XVIII wieku. Wyraźna opozycja między korzyściami wynikającymi z zachowania cnoty czystości a grzesznymi skutkami rozwiązłości miała nakłonić młode panny do rozważnego postępowania, a także do unikania roz- 
rywek i atrakcji znamiennych dla najbogatszej, wysoko urodzonej części ówczesnego społeczeństwa.

Struktura tego dzieła, korespondująca ze schematem gatunkowym modlitwy, miała na celu, jak można sądzić, wzmocnienie rangi przesłania tekstów zawartych w tym druku i nadanie im statusu wypowiedzi o charakterze katechetyczno-wychowawczym. Zbiór ten nie doczekał się wznowienia w samodzielnej edycji, nie trafił też do żadnego modlitewnika. Można zatem sądzić, że zachowanie cnoty czystości nie było ówcześnie doceniane ani szerzej propagowane, na przykład w programie wychowania młodych szlachcianek i arystokratek.

Druk miał prawdopodobnie tylko jedno wydanie. Dzieło zostało skatalogowane i nazwane od tytułu pierwszego tekstu: Modlitwa o zachowanie czystości [b.m.r., XVIII w.], 12º ss. 24, brak karty tytułowej. Jako podstawę wydania przyjęto egzemplarz druku w zbiorach Biblioteki Uniwersytetu Warszawskiego, sygn. 4g.15.2.60.

Tekst dzieła podany jest $\mathrm{w}$ zapisie zmodernizowanym. W transkrypcji zastosowano współczesny system interpunkcyjny. Znacznie ograniczono zakres stosowania wielkich liter (np. Aniołom $\rightarrow$ aniołom, Sakramentu Pokuty $\rightarrow$ sakramentu pokuty, Niebie $\rightarrow$ niebie), ponadto zmodernizowano pisownię łączną i rozdzielną (np. tym czasem $\rightarrow$ tymczasem, nie skromny $\rightarrow$ nieskromny, coby $\rightarrow$ co by). Głoski $i$ oraz $y$ transkrybowane są zgodnie ze współczesnymi regułami jako $i, y, j$ (np. daie $\rightarrow$ daje, okazya $\rightarrow$ okazja). Zmodernizowano również końcówki narzędnika 1. poj. r. m. i n. oraz l. mn. zaimków i przymiotników -em, -emi do postaci: -ym, -ymi (np. twemi $\rightarrow$ twymi, podobnemi $\rightarrow$ podobnymi). Nie zachowano zaznaczonego w podstawie wydania e pochylonego. Samogłoski nosowe transkrybowano według obowiązujących obecnie zasad (np. moię $\rightarrow$ moje, którę $\rightarrow$ które). Zmodernizowano pisownię samogłosek $o, o ́, u$. Występujące w druku długie $s(f)$ oddane jest jako $s$, zgodnie z dzisiejszą ortografią. Zmodernizowano pisownię spółgłosek dźwięcznych i bezdźwięcznych $t, d, s, z$ 
(np. roskoszq $\rightarrow$ rozkosza, ztwierdzana $\rightarrow$ stwierdzana). Zachowano niewystępujące już dziś oboczne tematy wyrazów (np. podchlebstwem $\rightarrow$ pochlebstwem, nadgrodzić $\rightarrow$ nagrodzić). Literę $x$ transkrybowano jako ks (xiążęta $\rightarrow$ książęta). W wyrazach obcego pochodzenia zredukowano podwójne formy (affektem $\rightarrow$ afektem). Zachowano występującą w druku grupę spółgłoskową -śrz- (śrzodki).

Dostrzeżone proste błędy druku poprawiono bez sygnalizowania tego w tekście. Uzupełniono sporadyczne braki znaków diakrytycznych (np. zastepow $\rightarrow$ zastępów, zabiegow $\rightarrow$ zabiegów, wieczor $\rightarrow$ wieczór). Poprawiono ponadto błędy drukarskie w zapisie samogłosek nosowych, a także oczywiste błędne litery (np. cienia $\rightarrow$ cienie, pogarszenia $\rightarrow$ pog<o $>$ rszenia). Te ostatnie zmiany zaznaczono w odpowiednich miejscach edytowanego tekstu.

\section{Modlitwa o zachowanie czystości}

Wszechmogący a nieograniczony Boże, spraw to, abym głęboko w sercu miała wrażone ${ }^{13}$ i często rozważała, że cnota jest ozdobą, a wstydliwość największą pochwałą rodzaju mojego, a tak będę szukać zaszczytu i uszczęśliwienia w cnocie, strzegąc czystości serca jako najmilszego i najwyższego skarbu.

Panie, cóż to jest życie moje? Postawa młodości mojej więdnie na wzór kwiatu. Kosztowna i najmodniejsza suknia nie potrafi ukryć zbrodni moich ani zalety ni pochwały mnie nie naprawią. Największe za tym powinnam łożyć staranie ku zjednaniu sobie upodobania Twojego, bo tu zasadza się los szczęścia mego, tak w życiu, jak i w wieczności.

O Panie, broń, abym nie była uwiedziona mylnym a zwodniczym podchlebstwem, rozkoszą, podarunkiem ni choćby przysięgą stwier-

13 wrazić/wrażać - wtykać, zapuszczać; tu wrażone: zakorzenione. 
dzaną ${ }^{14}$ obietnicą; smutne przykłady innych dla mnie niech będą przestrogą. Bym nie dała serca mego uwieść, lecz zawsze dostatecznie przezorną i ostrożną była. Te są przedsięwzięcia, które w obliczu Twoim, Boże, stanowię. Nie będę nic mówić ani słuchać przeciwnego panieńskiej skromności. Stanowię ${ }^{15}$ osobliwie w ubiorze i jestach być zawsze czystą, skromną i poważną. Płochy a nieskromny strój dalekim ode mnie będzie, który podłym daje okazją źle o nas trzymania ${ }^{16}$, wolno i zuchwale z nami postępowania, a często całe ${ }^{17}$ ścigania i rzucania sideł na ułowienie naszej czystości. Niech zna każdy $\mathrm{z}$ ułożenia ${ }^{18}$ mojego, jaki mam szacunek czystości a grozę zbrodni. Ty sam, o Panie, nadałeś osobliwszą ${ }^{19}$ powagę czystości, tak iż szczerze czystą i wstydliwą panienkę sami bezbożni poważają. Wstydliwość za tym będzie mi tarczą przeciw najazdom wszystkiej rozpusty.

O Boże, zachowaj mnie pierwszego upadku, bo pewno nie byłby i ostatnim. Pozwól mi w natarczywości pokus tyle czasu, abym wspomniała sobie na Twoją niewidzialną przytomność ${ }^{20}$. Jakżebym mogła odważyć się na tak wielką zbrodnią w obliczu Twoim? Czyż może być, abym grzeszyła przed Tobą, przeciw Tobie, o wielki a święty Boże? Atoli nie ma-ż tak grubych ciemności, które by mnie okryć mogły przed obliczem Twoim ${ }^{21}$. Twoje oko przenika wszystkie ciemności i tajemne zakąty. Tobie są wiadome myśli i żądania moje. Chociażby na krótki czas życia zdrożności moje przed oczyma świata utajone były, atoli jednak nie uszłabym sądów Twoich i kary nieochybnej ${ }^{22}$ występkowi. Bądź kiedykolwiek odkryłaby się moja hańba, ona momentalna rozkosz sprowadziłaby na mnie źrzódło gorzkich, ba,

\footnotetext{
14 stwierdzany - potwierdzany, utwierdzany.

15 stanowić (coś) - postanawiać, ustanowić (coś).

16 źle (o kimś) trzymać - źle (o kimś) mniemać, sądzić.

17 całe - wszystkie, ciągłe.

18 ułożenie - charakter, sposób postępowania, myślenia.

19 osobliwy - szczególny, nadzwyczajny.

20 przytomność - obecność.

21 Por. m.in. Ps 139.

22 nieochybny - pewny, nieomylny.
} 
krwawych łez ${ }^{23}$ i cierpienia, wraz z wiecznymi zarzuty i zgryzotami sumienia. Wraź tedy, o Stwórco serca mego, jak największy wstręt do tego, co by mnie przede mną samą i najczystszymi oczyma Twymi zawstydzić mogło, abym ciało moje w czystości zachowała i samotnie się nie kalała. Przeraź świętą bojaźnią serce moje, zahamuj smutnym i ostatecznym losem grzechowych rozkoszy namiętności moje, abym nie wpadła w bezedno ${ }^{24}$, w które lekkomyślność wprowadza.

Stawiaj w pamięci na każdy raz obraz śmierci i znikomości rzeczy ziemskich, które nas tak często łudzą i ku sobie ciągną. Cóż za korzyść w czasie z tego wszystkiego odniosę? Albo co w ostatnim zgonie $^{25}$ o tym sądzić będę? Mogęż być tak nieroztropną, abym najdroższy skarb, cnotę, honor, doczesne i wieczne szczęście, dla podłej i momentalnej rozkoszy traciła i razem wtrącała się w przepaść nieszczęśliwości? O Boże, niech zawsze mam wieczyste męki przed oczyma, owe męki, gdzie robak nigdy nie obumiera a ogień nie gaśnie ${ }^{26}$, gdzie nieczystych dusze wyłączone od widoku Twego oblicza (który samych czystego serca dusz nadgrodą jest) ${ }^{27}$ smutną pamiątką tak ważnej straty trapią się, wyrzucając sobie bezprzestannie, cóżem uczyniła. Cóżem to utraciła? Czymże być muszę? Oto wiecznie, z własnej winy, to uważając, ach Boże, mogęż się odważyć na stratę czystości? Albo mogęż dozwolić innym pociągać się i kusić do tego, co i najmniej obraża czystość? Będęż lekceważyć sobie te rzeczy, które prędzej lub później w życiu i wieczności okropne po sobie zostawują skutki? A wszakże gdybym się najbardziej raz odważyła, podobno nie byłabym w stanie życia mego odmienić i tak przyszłoby mi w grzechach umrzeć i zginąć na wieki.

23 krwawe łzy - symbol bolesnego doświadczenia zesłanego na człowieka przez Boga; nie można wykluczyć, że jest to aluzja do zdiagnozowanej już w połowie XVI wieku hemolakrii.

24 bezedno - przepaść.

25 ostatni zgon - odwołanie do Sądu Ostatecznego.

26 Por. Mk 9,44.

27 Por. Mt 5,8. 
Boże, strach mnie wskroś przeraża, drżę na wszystkich człon$\mathrm{kach}^{28}$, pamięć tępieje, krew się w siłach zsiada ${ }^{29}$, włosy na głowie do góry powstają, gdy to uważam. A jeszcze bardziej, gdy uważam wrodzoną słabość moję, przerażoną jestem. O, jak łatwo może mnie te nieszczęście spotkać, które tyle innych równego mnie stanu i wieku spotkało. Przeto będę czynić, co tylko możności będzie dla utrzymania czystości, unikając wszystkiego, co by ją o niebezpieczeństwo naraziło. A że nie jestem w stanie uniknienia i przejrzenia wszystkich okazji, przeto tym pilniej i przezorniej będę nad sobą czuwać i przez modły do Boga się uciekać, bym nie upadła w pokusy. Cale ${ }^{30}$ dziecinnym afektem udaję się do Ciebie, niebieski na każdym miejscu przytomny Ojcze. Znam ${ }^{31}$, że niczego nad siły po mnie nie wyciągasz $^{32}$, racz zatem niezdolne dziecię pragniące drogami praw Twoich chodzić, prowadzić, strzec i umacniać. O to upraszam, tego się spodziewam przez zasługi Jezusa Chrystusa, Syna Twego, Pana naszego. Amen.

Najświętsza Panno i Matko Boga Maryja, przedziwny wzorze czystego życia, bądź mi protektorką u Syna twego, abym nic nie czyniła ani myśliła, co by mnie przed Bogiem obwiniło. Uproś mi łaski, abym miała zawsze święte nauki i przykłady twojego Syna przed oczyma, a tak chroniąc się nie tylko okazji, ale i samego cieniu grzechowego ${ }^{33}$, w czasie czystą i niepokalaną przed obliczem Boga stanąć mogła.

28 drżeć na wszystkich członkach - odczuwać drżenie, poruszenie przemienne, mimowolne, niepożądane na całym ciele.

29 krew się $w$ siłach zsiada - wyrażenie to oddaje ludowe przekonanie, że typowym objawem przerażenia i lęku jest krzepnięcie krwi i osłabienie; współcześnie zwrot ten funkcjonuje jako frazeologizm: „coś mrozi krew w żyłach”.

30 cale - zupełnie.

31 znać-wiedzieć.

32 wyciągać (coś po kimś) - wymagać, żądać.

33 Określenie cieniu grzechowego wiąże się z przestrogą dotyczącą zapewne unikania postępowania, które wprawdzie nie ma jeszcze znamion grzechu, ale jest do niego zbliżone i niechybnie niebawem nim się stanie. 


\section{Pożytki cnoty czystości}

1. Czystość czyni nas Bogu i aniołom podobnymi i ma osobliwszą chwałę w niebie; świadkiem jest tego Pismo Święte i ojcowie święci $^{34}$. Nieczystość zaś upodla nas nad samych czartów ${ }^{35}$.

2. Nieczystość szkodzi zdrowiu i życiu, czystość utrzymuje tak zdrowie, jak życie. O, jak wiele młodzianów i panienek zawarła nieczystość przed czasem w grobowych mogiłach, wiele innych prowadzą zrujnowane na siłach nieczystością życie, chodzą wycieńczeni jako cienie śmierci i martwe poczwary. Któż może i mianować ${ }^{36}$ haniebne choroby, które nieczystość płodzi? Nieczysta grzeszy ciałem, a zatem na ciele osłabionym, bezwładnym, skaleczałym ${ }^{37}$ i cale zeszpeconym najpierwsze zbiera owoce. ( ${ }^{\star} \mathrm{Je}$ żeli nie wierzysz, idź tylko po łazaretach ${ }^{38}$, a przekonasz się $\left.{ }^{39}\right)$.

3. Nieczystość osłabia siły duszy, czystość umacnia i ożywia je. Tak jako ciało trawi się nierządnym ogniem wszeteczności i na wzór zwiędłego kwiatu upada, podobnież tępieje pamięć z nadwątloną siłą życia nieczystością i rozum skłania się do bydlęcej niepojętości. Nie trzeba się dziwić, że gdy rozumne stworzenia puszczają się za namiętnościami ciała, jak muł i osieł, iż potem i na rozumie stają się podobnymi nierozumnemu mułowi i osłowi. Tym-

$34 \mathrm{~W}$ celu wzmocnienia racji przedstawionych w pierwszym tekście $\mathrm{z}$ drugiej części zbioru autor sięga po argumenty z autorytetu, po czym odwołuje się do realiów związanych z życiowym doświadczeniem, wskazując przykłady chorób, a nawet śmierci z powodu rozwiązłego trybu życia.

35 nad... czartów - bardziej niż czartów.

36 mianować - nazywać

37 skaleczały - niedołężny

38 łazarety/lazarety - szpitale

39 Nawiązując do faktu, iż wśród pacjentów miejskich lazaretów sporą część stanowiły cierpiące na choroby weneryczne osoby, które trudniły się nierządem, autor potwierdzał pełną zasadność formułowanych przestróg. Miasto uznawane było za siedlisko zepsucia moralnego i rozpusty i może to właśnie było głównym powodem do przypomnienia o randze cnoty czystości. Zob. T. Kostkiewiczowa, Wizje miasta $w$ literaturze wieku Oświecenia, w: eadem, Oświecenie próg naszej współczesności, Warszawa 1994, s. 144-162. 
czasem dusza szlachetna i czysta o jak wiele pojmuje, rozumie, docieka tych rzeczy, które dla nieczystej są tajemnicą, na wysokie, niedościgłe i boskie? Bo czyliż będzie mógł Duch mądrości mieszkać w sercu nieczystym ${ }^{40}$.

4. Nieczystość przynosi hańbę, czystość wieńczy skronie swoich kochanków nieskażytelnej chwały laurem. Nieczyści doznają tego najlepiej, że hańba jest ich zdobyczą. Bo dlaczegoż chowa się, popełniając nieczystość? Dlaczegoż zaczerwienia się przy najmniejszej podanej porozumienia okazji? Jest to prawda, że można przyjść do tego stopnia, że już ani się czerwienić, ani tajemnych miejsc szukać będzie do spraw ciemności. Atoli natenczas utraciwszy wszelką czułość i poczciwość, wpada w największą niesławę. Nie tak postępuje sobie czysta. Ona nie ma się czego oka ludzkiego wstydzić. Cnotliwy zachodzi jej drogę z szacunkiem, a nieczysty pogląda ${ }^{41}$ na nią z zadziwieniem, nie mogąc pojąć jego męstwa w pokonaniu namiętności grzechowej, które jego jako niewolnika w swoich więzach trzymają.

5. Nieczystość kala i obciąża sumienie, czystość je rozwesela. Chociażby nieczysta w największych rozkoszach opływała, serce jej jednak nie będzie spokojne. Sumienie woła na nią nader głośno: „Uniżyłaś się aż do klasy bydląt, stałaś się gorszycielem niewinności. O, jak wielu stałaś się przyczyną nieszczęścia, hańby i niedostatku? O, jak obszernie rozlały się pogorszenia ${ }^{42}$ twoje? O, jak obrzydłą stałaś się przed obliczem Boga i uczciwych ludzi”. Tymczasem czysta nosi zawsze cechę radości w swoim sercu.

6. Nieczystość jest zarazą familiii ${ }^{43}$, towarzystwa, pospólstwa ${ }^{44}$ i całej ludności. Czystość jest jej błogosławieństwem, kto pojąć to może, niech pojmuje. Nieczystość zaraża potomstwo: niszczy narody

\footnotetext{
40 Por. $\mathrm{Rz} 8,9$.

41 poglądać - spoglądać

42 pogarszenia $\rightarrow$ pog<o $>$ rszenia; poprawka wydawcy, błąd druku.

43 familia - rodzina, ród

44 pospólstwo - społeczeństwo
} 
i książęta, niewiasty i mężczyzny, rodzice i dzieci, słowem: cały naród ludzki.

7. Nieczystość przynosi trwogę i nieufność w Bogu. Czystość wpaja w serce dziecinne zaufanie. Nieczysta nie śmie oczu podnieść do Boga, tymczasem przyjaciółka czystości wznosi oczy swoje śmiało do niepokalanego zastępów Boga ${ }^{45}$, którego oczy jako błyskawica, a skaza nie postała w nim.

8. Nieczystość zamyka niebo a wtrąca do piekła. Czystość i niewinność jedna ${ }^{46}$ widzenie Boga, prowadzi do przestawania $\mathrm{z}$ Jezusem Chrystusem w wiecznej chwale. Błogosławieni są czystego serca, albowiem oni Boga oglądać będą.

\section{Niebezpieczeństwa,}

których się cnotliwa panienka osobliwie strzec $\mathrm{ma}^{47}$

1. Próżność, pragnienie podobania się jest to zwyczaj najpierwszym krokiem do upadku; staraj się tylko podobać Bogu, a tak podobasz się i ludziom, których przyjaźń może ci być pożyteczną.

2. Ubiór nieskromny, lekkomyślne wdzięki, są sidłem w których samochcąc ${ }^{48}$ się więzisz. Skromność jest największą ozdobą panien.

45 niepokalanego zastępów Boga - wyrażenie to podkreśla bezgrzeszną naturę Boga, a także Jego panowanie nad wszelkimi siłami. „Pan zastępów” to dawne określenie Boga, który przez swą obecność w Arce Przymierza miał zapewniać

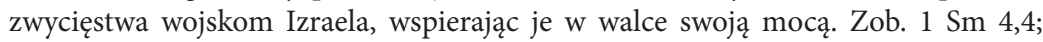
Rz 9,29; Jk 5,4.

46 jednać (sobie coś) - kształtować

${ }^{47}$ W tej części druku konkretne niebezpieczeństwa odwołują się do obaw związanych z salonowym flirtem - zjawiskiem tak popularnym i ważnym w kulturze oświecenia. Zob. m.in. J. Ryba, Ślady „żywiołu towarzysko-salonowego” w poezji Wojciecha Miera, w: idem, Oświeceniowe „tutti frutti”. Maskarady - konwersacja literatura, Katowice 2009, s. 141-152; K. Stasiewicz, Kobiece przyjemności w XVIII wieku..., s. 137.

48 samochcac - dobrowolnie, nieprzymuszenie 
3. Wielkie jest, które za prędko myślą o swoim postanowieniu, a że mylnych używają zabiegów, tracą prawdziwy los szczęścia, który im Opatrzność nagotowała ${ }^{49}$. Ty za tym staraj się uprzątnąć przeszkody do uszczęśliwienia losu i nadto usiłuj zasłużyć go sobie przez dobre postępki. Z resztą spuść się na Opatrzność Boga, która pewne ma staranie i pieczą o tobie.

4. Kto ci podchlebia, ten pewno nieszczerze $z$ tobą postępuje, lecz pogardza i za bezrozumną ciebie ma, a za tym godzien jest, abyś nim nawzajem gardziła. Obietnice rozwiązłych ludzi są mylne, którzy nie ciebie kochają, tylko lubieżność. Czegoż dobrego możesz się spodziewać po obłudniku, który Boga się nie boi, albo któż ci potrafi nadgrodzić stratę honoru i cnoty, którą on ci odebrać usiłuje?

5. Z żadnym mężczyzną nie przestawaj na osobności i poufale, a za tym bardziej nocną porą ${ }^{50}$. Choćbyś najpoczciwiej w początkach przestawała, jednak podajesz niewinność twoją w niebezpieczeństwo. Większa część miłośnego przestawania zły koniec bierze; gdzie nieskromność panuje, tam niech noga twoja nie postanie, albowiem tam śmierć, grzech i szatan wchodzi i wychodzi.

6. Nie waż sobie lekce, by i najmniej przeciwiało się panieńskiej skromności. Od małych poufałości, żarcików i nieprzyzwoitości zaczyna się, a po tym coraz się więcej śmiałości nabiera, na koniec grzeszy się bezwstydnie.

7. Poufałe pooglądania i jesta, nieczyste mowy i piosnki, nieprzystojne żarciki i łechtania prawie gwałtem wzbudzają złe żądze. Odwracaj zatem oczy, uszy i myśli od tego. Okaż nieukontentowanie i obróć do czego innego mowę, słowem - nie przestawaj cale $\mathrm{z}$ takimi ludźmi, co się w tym kochają.

49 nagotować - przygotować

50 Katalog pokus uznanych przez autora za przyczynę wszelkiego zła i grzechu opiera się na założeniu, że wszędzie wokół szerzy się lubieżność. W związku z tym dobrze wychowana i pobożna panna nigdy nie powinna pozostawać na osobności z mężczyzną. 
8. Unikaj płochych rozrywek. Rozwiązłe tańce są grobem niewinności. Staraj się usilnie być skromną i stateczną. To, co ci odbiera skromność, odbiera i czystość; wstydliwość jest hamulcem nieczystości, kto hamulec odrzuca, otwiera bramę nieczystości. Zawczasu ucz się poskramiać namiętności i żądze.

9. Wiesz, co może być największym niebezpieczeństwem, za tym strzeż się tego i miej się na ostrożności; obierz sobie niewinne rozrywki, których byś się nie wstydziła w czasie i nie żałowała. Niewinność jest zawsze spokojna i wesoła. Panienka nie jest pochmurną i kłótliwą dewotką.

10. Zawsze się czym zatrudnić, abyś nie miała czasu bawienia się złymi myślami. Próżnowanie płodzi złe myśli, żądze i imaginacyje. Nie baw się z lenistwem w łóżku, gdyż się już spać nie chce, wstań zawczasu i śpieszno osobliwie w dni święte. Dla oddania twego serca Bogu zaraz od rana.

11. Nie czytaj niebezpiecznych romansów i serce psujących książek. Takowe czytania wzbudzają namiętności i rozpalają krew, ożywiają złe fantazje, wzbudzają żądze, łudzą serce, sprawują niechęć do dobrego i pracy, słodzą zbrodnie, na koniec stają się nałogiem i jakoby drugą naturą człowieka ${ }^{51}$.

12. Strzeż się zbytku w jedzeniu i piciu. To bowiem oburza wszystkie namiętności, a rozum pokrywa ciemności obłokiem, odbiera wszelki wstyd i szacunek siebie samego, odbiera wszelką chęć

$51 \mathrm{Na}$ negatywne konsekwencje czytania romansów przez młode kobiety zwracali już uwagę oświeceniowi publicyści. Zob. Z. Sinko: Sądy Oświecenia o dawnym romansie i „nowej” powieści, w: eadem, Powieść zachodnioeuropejska w kulturze literackiej polskiego Oświecenia, Wrocław 1968, s. 54-92; B. Mazurkowa, Oświeceniowi literaci, wydawcy i drukarze o czytelnikach, czytaniu oraz „ladajakich”, zakazanych $i$ szacownych ksiegach, w: eadem, Weksle prawdy i nieprawdy. Studia literackie o książce oświeceniowej, Warszawa 2011, s. 43-47. Podobne zalecenia zawarte są w publikowanych ówcześnie (oryginalnych i tłumaczonych) utworach poetyckich. Zob. m.in. F. Zabłocki, Rady młodej Dorotce dane [z francuskiego], w: idem, Pisma, wyd. B. Erzepki, Poznań 1903, s. 319-327; F. Karpiński, Wiersz do młodej panienki, w: idem, Wiersze zebrane, cz. 1, wyd. T. Chachulski, Warszawa 2005, s. 181-182. 
cnoty i czyni największe zdrożności nieuchronnymi. Człowiek niewstrzemięźliwy nie może czynić, co chce dobrego, a czyni wiele złego po niewoli.

13. Strzeż się pierwszego grzechu i pożądliwości, która serce kala, albowiem pierwszy grzech jest wielkim krokiem na potępienie ${ }^{52}$.

Śrzodki do zachowania panieńskiej czystości

Czuwaj a módl się.

1. Czuwaj, uważaj pilnie, co się w tobie dzieje, potłumiaj zaraz w początku powstające nieczyste wzruszenia i skłonności, potem za późno już będzie. Nie myślić, że tylko ten raz, za każdym zezwoleniem stajesz się słabsza i upadasz głębiej.

Znaj słabość twoję, nie dowierzaj samej sobie. Gdy widzisz inne upadające, nie sądź, żeś jest lepszą, nie naśmiewaj się, lecz niech ci to będzie przestrogą. Ucz się pokory, pycha poprzedza upadek. Bądź ostrożną i mężną, gdy się ku tobie podchlebca zbliża. Stroń i oddal się od niego, na koniec wzywaj ratunku. Nie tak łatwo można wydrzeć panience, co jej jest najmilszego.

Szanuj sama siebie, jeżeli chcesz być szanowaną. Zachowuj ciało swoje w świątobliwości, które jest żywym kościołem Boga i członkiem ciała Jezusa Chrystusa i w samotności nie zapominaj na wstydliwość, bo ta jest aniołem i stróżem czystości.

2. Módl się często, szczerze, krótko a dobrze. Wstając, polecaj się Bogu, zastanów się, w jakie okazje i pokusy wpaść możesz i jak się w nich zachować masz. Na wieczór przypomnij sobie, jakieś przedsięwzięcia zachowała, ponów je, wykroczenia obżałuj ${ }^{53}$ i tak zabieraj się do spoczynku w świętych myślach.

52 Dramaturgię zarysowanych scen i zawartego w nich moralnego przesłania wzmacnia akcentowana świadomość nieuniknionych konsekwencji popełnianych czynów; jak przekonuje bowiem autor - nawet jednorazowy grzech może doprowadzić do wiecznego potępienia.

53 obżałować/ożalić - opłakać. 
Przez dzień pamiętaj często na obecność Boską i chodź na każdy raz w przytomności Jego. W ciężkich pokusach, jeżeli chociaż na moment do Boga rzucisz okiem. Twego wszystko widzącego Ojca i Sędziego pewno nie zgrzeszysz. Atoli, żebyś miała być tak nieszczęśliwą i zgrzeszyła tedy natychmiast skruszonym sercem udaj się do Boga, ponów przedsięwzięcia, bądź ostrożniejsza na przyszłą a nie rozpaczaj.

Umacniaj się w przedsięwzięciach częstym a godnym przyjmowaniem sakramentu pokuty i Ciała Pańskiego, usiłuj coraz być lepszą i czystszą na sumieniu. Niedziele i święta przepędzać zbawiennie. Z każdego kazania zachować sobie to, co się najwięcej ciebie tyczy i często sobie to przypominaj.

Zachowaj żywą pamięć konającego Jezusa Chrystusa, który tak surowe męki cierpiał dla oczyszczenia nas z grzechu. Mów sama do siebie w okazjach grzechowych: „Jezus pił kielich goryczy sromotnej śmierci dla zbawienia mego, a ja miałabym pić truciznę wszeteczności na potępienie?”.

Idąc przez cmentarz, przy zdarzonej raptownej śmierci, przy grobie znajomych słysząc dzwonienie, pamiętaj na zbliżającą się śmierć, wieczność i smutny koniec światowych rozkoszy i wszelkich rozrywek. Uważaj ${ }^{54}$ konających, a pamiętaj, że i ciebie toż czeka.

Dochowuj wiary ciała zmartwychwstania i sądu. Pamiętaj na to, że cokolwiek człowiek wysieje, to też i zbierać będzie, dzień żniwa jest dzień zmartwychwstania i Sądu Ostatecznego ${ }^{55}$. O, jak natenczas zawstydzoną, pohańbioną i obrzydłą powstanie z grobu nieczysta, która ciało swoje kalała. Wyrok jej sądu będzie: „Idźcie precz, nieczyści, w ogień wieczny". Kto wierny i pamięta o tym, na pewno nie zgrzeszy.

54 uważać - mieć wzgląd na coś/kogoś.

55 Por. Ga 6,8. 
Staraj się często z uwagą przeczytać te przestrogi, jeżeli nie co tydzień, to chociaż co miesiąc. Amen.

\section{Bibliografia}

Aleksandrowska E., Problem zdrady na podstawie „Satyr i pamfletów na Polki balujace $w$ czasach tragicznych dla ojczyzny” (1774-1832), w: „Bo insza jest rzecz zdradzić, insza dać się złudzić". Problem zdrady w Polsce przełomu XVIII i XIX wieku, red. A. Grześkowiak-Krwawicz, Warszawa 1995.

Dębowski M., Zabawy przyjemne i pożyteczne w oświeconej alkowie, w: Przyjemność w kulturze epoki rozumu, red. T. Kostkiewiczowa, Warszawa 2011.

Doktór R., Wizerunek Matki Boskiej w poezji polskiej XVIII wieku, w: Literatura, historia, dziedzictwo. Prace ofiarowane profesor Teresie Kostkiewiczowej, red. T. Chachulski, A. Grześkowiak-Krwawicz, Warszawa 2006.

Karpiński F., Wiersze zebrane, cz. 1, wyd. T. Chachulski, Warszawa 2005.

Kitowicz J., Opis obyczajów za panowania Augusta III, wstęp M. Dernałowicz, red. Z. Goliński, oprac. A. Skarżyńska, Warszawa 1985.

Kostkiewiczowa T., Jak poeci polscy drugiej połowy XVIII wieku mówili o Bogu i szatanie, w: Tysiąc lat polskiego stownictwa religijnego, red. B. Kreja, Gdańsk 1999.

Kostkiewiczowa T., Poezja religijna czasów Oświecenia, w: Polska liryka religijna, red. S. Sawicki, P. Nowaczyński, Lublin 1983.

Kostkiewiczowa T., Wizje miasta w literaturze wieku Oświecenia, w: eadem, Oświecenie próg naszej wspótczesności, Warszawa 1994.

Krosny A., Z ulicy na salony. Awans społeczny w świecie prostytucji w wieku XVIII, w: Wiek XVIII (nie tylko) w szkole. Literatura - historia - kultura - sztuka, red. B. Mazurkowa, z udziałem M. Marcinkowskiej, Katowice 2013.

Maciejewski J., Wstęp, w: Literatura barska. Antologia, oprac. J. Maciejewski, wyd. 2 zupełnie zmienione, Wrocław 1976.

Mazur J., Rogowicz K., Literaci XVIII wieku o kobiecych piersiach i dekoltach, w: Wiek XVIII (nie tylko) w szkole. Literatura - historia - kultura - sztuka, red. B. Mazurkowa, z udziałem M. Marcinkowskiej, Katowice 2013.

Mazurkowa B., Oświeceniowi literaci, wydawcy i drukarze o czytelnikach, czytaniu oraz „ladajakich”, zakazanych i szacownych ksiegach, w: eadem, Weksle prawdy i nieprawdy. Studia literackie o książce oświeceniowej, Warszawa 2011.

Michałowski S.W., Przestrogi i uwagi nad obowiązkami każdego stanu, pobudzajace chrześcijan do zadosyć czynienia powołaniu ich. Dzieło pożyteczne. Wszystkim którzy żyć pragna duchem prawdziwej i gruntownej pobożności, wydane najprzód $\mathrm{w}$ francuskim języku, $\mathrm{z}$ francuskiego na włoski, a teraz $\mathrm{z}$ włoskiego 
na polski język przetłumaczone. przez jednego zakonnika Scholarum Piarum, książka pierwsza, Warszawa 1768.

Modlitwa o zachowanie czystości, b. m. r. [XVIII w.].

Ryba J., Ślady „żywiołu towarzysko-salonowego” w poezji Wojciecha Miera, w: idem, Oświeceniowe „tutti frutti”. Maskarady - konwersacja - literatura, Katowice 2009.

Salezy F., Przestroga dla spowiedników, sposób odprawowania pobożnie Mszy Świętej, przygotowanie się do Komunii Świętej przez uwagi zbawienne, akty różne strzeliste, modlitwy i zabawy pobożne, $\mathrm{z}$ francuskiego na polskie przetłumaczone, Kraków 1793.

Snopek J., Libertynizm, w: Stownik literatury polskiego oświecenia, red. T. Kostkiewiczowa, wyd. 2 poszerzone i poprawione, Wrocław 1991.

Snopek J., Objawienie i Oświecenie: $z$ dziejów libertynizmu w Polsce, Wrocław 1986.

Stasiewicz K., Kobiece przyjemności w XVIII wieku, w: Przyjemność w kulturze epoki rozumu, red. T. Kostkiewiczowa, Warszawa 2011.

Ślusarska M., Przyjemności „wszeteczne”, czyli o prostytucji $w$ Warszawie stanisławowskiej, w: Przyjemność w kulturze epoki rozumu, red. T. Kostkiewiczowa, Warszawa 2011.

Wojtak M., Modlitwa ustalona - podstawowe wyznaczniki gatunku, w: W zwierciadle języka i kultury, red. J. Adamowski, S. Niebrzegowska, Lublin 1999. 